\section{$1 \mathrm{R0930}$}

\section{G タンパク質結合選択性に相関性のある GPCRの配 列及び構造的特徵}

○村松 孝彦 1 、諏訪牧子 1 $^{1}$ (産業技術総合研究所 生命情 報科学研究センター、2 産業技術総合研究所 生命情報科学 研究センター)

$\mathrm{G}$ タンパク質共役型受容体 (GPCR) は、細胞外部から内部への情報 伝達という再で、非常に重要な役割を担っている。近年、多くの新規 GPCR が発見されており、今後はこれらの機能解析が重要な課題と なっている。Gタンパク質結合選択性の機能メカニズムについては、 その重要性にもかかわらずほとんど理解されておらず、新規 GPCR の配列が決まっても結合選択性を予測することは難しい。結合選択性 に関わる要因を明らかにするために、その配列的特徽やロドプシンを

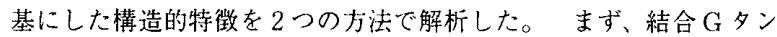
パク質既知の GPCRについて、様々な物理量で記述し、各变量間の 相関性を解析した。その結果、膜外ドメインの長さ及び平均疎水性傎 などの変量と結合選択性の間に相関性が得られた。また、以下の仮 定を执いて、GPCRの残基レベルでの解析を行った。Class A GPCR はいくつかの非常に保存性の高い残基が存在し、それらは立体構造を 形成する上で重要な役割を担っている。よって、そのような残基はへ リックス上に拈ける位置はだいたい同じであると考えられる。このよ うな仮定により、膜貫通ドメインごとに多重配列アラインメントを行 いその結果により各アミノ酸残基のへリックス上の位置を予測でき る。予測した位置における GPCR の結合選択性別のアミノ酸組成を 計算し、その違いについて解析した。その結果、結合選択性を決定付 けるような残基は存在しなかったが、いくつかの結合選択性と相関性 のある残基を発見した。本会では、これらの結果を基に結合選択性 に相関性のある GPCR の配列及び構造的特徴について埭論する。

T.MURAMATSE and M.SLWA : Seruener and structural relationship between GPCR and G-protein selectivity.

\section{R1000}

バーチャル・フォールド・シミュレーション: 二次構 造の空間配置からのトポロジー予測

○石田裕一、白井㴊、堀田秋津、山根隆 (名大·院工. 生 物機能工学)

近年、構造ゲノミクスの成果によりめまぐるしい速度でタンパク質 立体構造が決定されているが、フォールドレベルでみると、その数 は数百程度しか分かっていない。そこで、コンピュータを利用して タンパク質を構成している二次構造の空間配置についての経験則を 抽出し、この経験則を利用してタンパク質フォールドを網羅的に法 定するためのシステムVirtual fold simulation(VFS)の開発を行った。 このシステムでは、-次構造要素をタンパク質のパーツとして扱い、 それを組み立てることによってタンパク質フォールドを生産する。 そのため、VFSを利用することで未だ見つかっていないものをコン ピュータ上で予測することが可能である。VFSではタンパク質内部 に見られる二次構造要素をべクトルとして表現し、組み合わること によって、タンパク質フォールドを生産する。この生産されたフォ 一ルドが現在までに分かっているものとは異なる場合、このフォー ルドを人エタンパク質設計への足場として応用可能である。しかし、 VFSで生産されたフォールドはシステムの関係上、“...次構造要素の つながり方を考虑していない。実際のタンパク質は一本のペブチド が折りたたまって扔り、人コ.タンパク質設計への惢用にはトポロジ 一を決定する必要がある。そこで、ベクトル表現されているタンパ ク質フォールドのトポロジー予湘システムの開発を行った。このシ ステムでは、タンパク翼立体構造内で見られる連続する二次構造の 空間配置から得られる経験則を用いて、“次構造のつながり方を評 価している。詳細な方法や結果については本年会にて報告する预定 である。

H.Ishida, T.Shirai,A.Hotta and T.Yamann : Virtual fold simulation: Topology prediction from the space arrangement of secondary structuress

\section{R0945}

予測法と実験の組合せによる網羅的膜貫通トポロジー 決定

○池田 修已、夏俊雄、新居 真吏、清水 俊夫（弘前大理工電 子情報システム工学)

膜貫通 (TM) タンパク質の機能分類・同定を配列類似性だけで行う のは困難である（現時点で高々 $40 \%$ 程度）が、TM トポロジー情報 と組み合せて行えば、それがかなりの程度改善されることが分かっ ている。しかしながら、実験による TMトポロジーデー夕は決定的 に不足して拉り、予測法によるトポロジー情報に頼らざるを得ない のであるが、その予測精度は十分には高いものではないというのが 現状である。同時に、このトポロジーデータ不足が、TMトポロジ 一予測法の精度を思うようには高められない主な原因にもなってい る。やはり、できるだけ多くの TM トポロジーデー夕を実駼によっ て獲得する必要がある。いくつかの予測法の予測結果をうまく組み 合せることによってトポロジー（TM セグメント本数のみ）決定に 必要な実験量を大幅に減らすことができることを、von Heijne らが すでに報告している。本発表では、TM セグメント本数だけではな くセグメント位置をも同時に、できるだけ少ない実験量で決定する 方法の提案を行う。これは、ある特定の 5 つの方法が本数・位置と もに同じ尒測結果を与える場合は、予測トポロジーモデルをそのま まトポロジーデータとすることができ、予測結果が本数 1 本違いで 4:1 あるいは 3:2 と割れる場合には、C端ループが細胞内か細胞外か だけを実験で決めることによって、どちらか一方のトポロジーモデ ルをトポロジーデータとすることができる、というものである。 我々の試算では、このようなやり方だけで、大腸菌 $951 \mathrm{TM}$ タンパ ク質配列中の 450 配列のトポロジーを、ヒト 6,582 配列中の 3,794 卜 ボロジーを決定できる。

M. Ikeda, S. Ka, .. Arai and T. Shimizu: Comprehensive mapping of transmembranc topologies

\section{$1 \mathrm{R} 1015$}

\section{蛋白質の複合体形成に伴う立体構造変化に関する研究}

○上野次郎、池口満德、木寺 詔紀（横浜市立・総合理学）

蛋白質の分子結合や反応に伴う構造変化は、構造と機能の相関解析に おいて重要な課題である。本研究では基質との相互作用などの搑動を 加えた時の構造変化を子測する方法の開発を行った。

蛋白質を構成する原子の位置を確率分作としてとらえ、基質との相互 作用などによる掑動を外力として考えることにより、掑動と構造变化 の関係の理論の定式化を行った。その結果、外力と非椇動状態の構造 の熱ゆらぎを用いて、構造変化を予測できる式を導出した。 この式の妥当性を評価するために、デヒドロ葉酸還元醅素 (DHFR) の既知の構造变化に本方法を適用した。非掑動状態の構造の熱ゆらぎ は、分子動力学法と、異方性ネットワークモデル (ANM)のそれぞれ により算出する方法を試みた。その結果、補醰素の結合様式の変化が 構造の熱ゆらざを通してドメインモーションのような大きな領域の構 造変化を引き起こすことが示された。

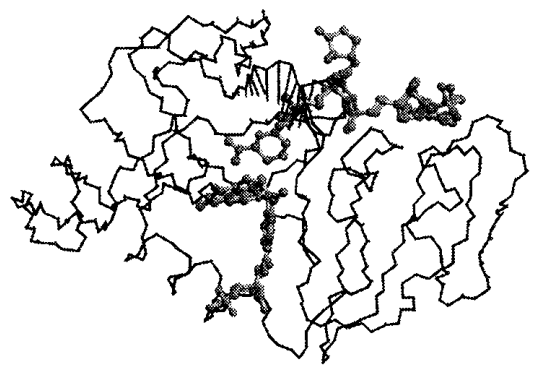

J.Geno, M.Ikeguchi, A.kidera : A study of protein structual changes associated with comprex formation. 